\title{
Stimulation of the parietal cortex affects reaching in a patient with epilepsy
}

\author{
田
}

Figure (A) MRI left hemisphere cortex rendering with positions of the grid electrodes superimposed (lesion in blue on the mesial side) and (B) video still of the reaching arrest and posturing during stimulation of electrode pair 37-45

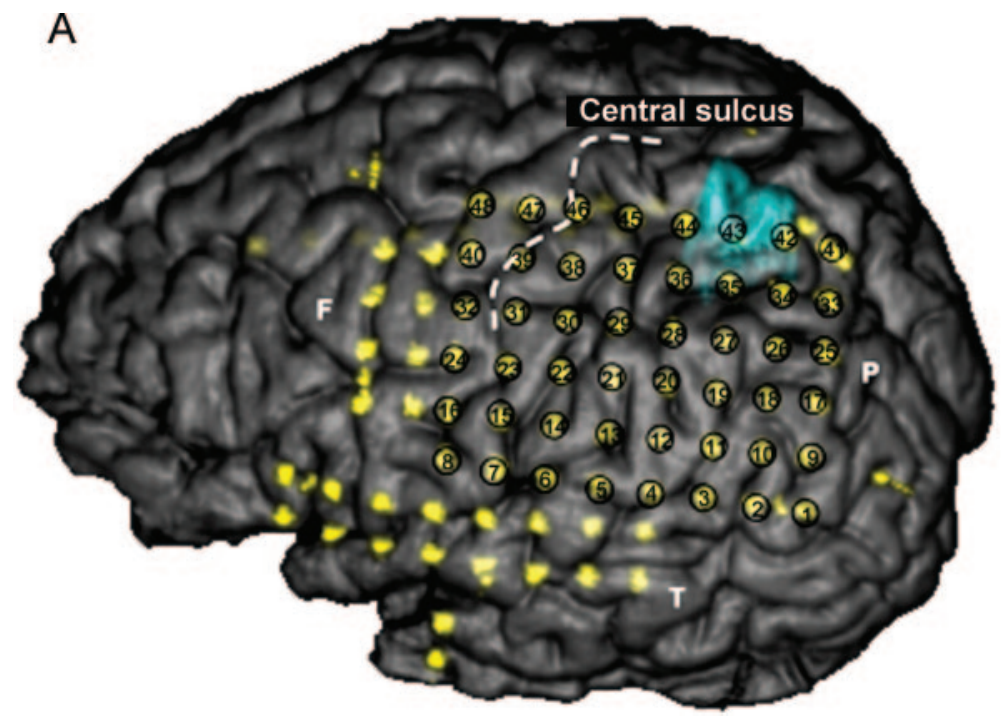

B

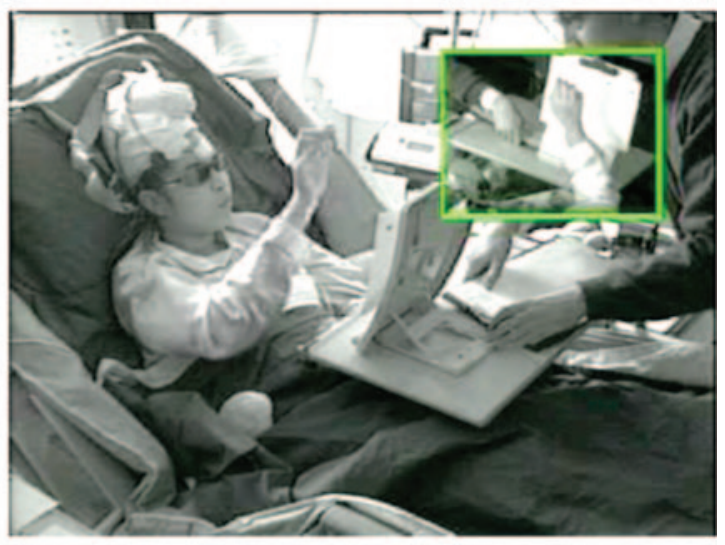

A 15-year-old girl with complex partial epilepsy had subdural electrodes implanted. She was tested on reaching tasks during electrocortical stimulation prior to neurosurgery. MRI showed left mesial parietal dysplasia. Stimulation of the superior parietal cortex (electrode pair 37-45, figure, A) during line bisection and visually guided reaching resulted in movement arrest followed by the arm drifting upward (figure, B, videos 1 and 2 on the Neurology ${ }^{\circledR}$ Web site at www.neurology.org). Stimulation of these electrodes also resulted in reaching arrest when aiming toward proprioceptive targets (video 3). These observations are consistent with the idea that superior parietal cortex contains representations of defensive arm postures ${ }^{1}$ or is involved in sensoryguided reaching. ${ }^{2}$

H.C. Dijkerman, DPhil, J. Meekes, MSc, A. Ter Horst, MSc, W.P.J. Spetgens, REEGT, E.H.F. de Haan, PhD, F.S.S. Leijten, MD, PhD, Utrecht, Woerden, and Amsterdam, the Netherlands

Disclosure: Dr. Dijkerman receives research support from The Netherlands Organisation for Scientific Research [452-03-325 (PI) and 400-04-379 (PI)] and serves on the editorial advisory board of Neuropsychologia. J. Meekes has received research support from Stichting Bio. A. Ter Horst and W.P.J. Spetgens report no disclosures. Dr. de Haan serves on a scientific advisory board for OTS [Onderzoeksinstituut voor Taal en Spraak (research institute for language and speech)], Utrecht, the Netherlands, and MPI [Max Planck Institute for Psycholinguistics], Nijmegen, the Netherlands; and serves on the editorial board of the Journal of Neuropsychology. Dr. Leijten reports no disclosures.

Address correspondence and reprint requests to Dr. H.C. Dijkerman, Experimental Psychology, Helmholtz Institute, Utrecht University, Heidelberglaan 2, 3584 CS Utrecht, the Netherlands; c.dijkerman@uu.nl

Supplemental data at www.neurology.org
1. Graziano MS, Cooke DF. Parieto-frontal interactions, personal space, and defensive behavior. Neuropsychologia 2006;44:845859.

2. Prado J, Clavagnier S, Otzenberger H, Scheiber C, Kennedy H, Perenin MT. Two cortical systems for reaching in central and peripheral vision. Neuron 2005;48:849-858. 


\section{Neurology}

\section{Stimulation of the parietal cortex affects reaching in a patient with epilepsy}

H. C. Dijkerman, J. Meekes, A. Ter Horst, et al.

Neurology 2009;73;2130

DOI 10.1212/WNL.0b013e3181c67999

This information is current as of December 14, 2009

\section{Updated Information \&}

Services

Supplementary Material

\section{References}

Subspecialty Collections

Permissions \& Licensing

Reprints including high resolution figures, can be found at: http://n.neurology.org/content/73/24/2130.full

Supplementary material can be found at: http://n.neurology.org/content/suppl/2009/12/13/73.24.2130.DC1

This article cites 2 articles, 0 of which you can access for free at: http://n.neurology.org/content/73/24/2130.full\#ref-list-1

This article, along with others on similar topics, appears in the following collection(s):

Cortical localization

http://n.neurology.org/cgi/collection/cortical_localization

Epilepsy surgery

http://n.neurology.org/cgi/collection/epilepsy_surgery_

Motor Control

http://n.neurology.org/cgi/collection/motor_control

Video/ EEG use in epilepsy

http://n.neurology.org/cgi/collection/video_eeg_use_in_epilepsy

Information about reproducing this article in parts (figures,tables) or in its entirety can be found online at:

http://www.neurology.org/about/about_the_journal\#permissions

Information about ordering reprints can be found online:

http://n.neurology.org/subscribers/advertise

Neurology ${ }^{\circledR}$ is the official journal of the American Academy of Neurology. Published continuously since 1951, it is now a weekly with 48 issues per year. Copyright. All rights reserved. Print ISSN: 0028-3878. Online ISSN: 1526-632X.

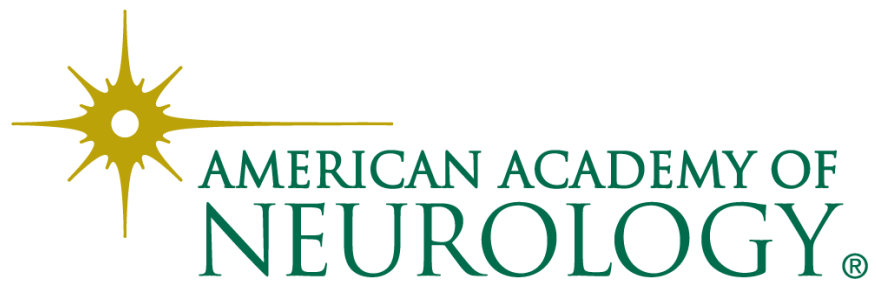

